Åsa Wedin*

\title{
Ideological and implementational spaces for translanguaging in the language introduction programme in Swedish Upper Secondary School
}

https://doi.org/10.1515/multi-2021-0126

Received October 15, 2021; accepted November 5, 2021; published online November 25, 2021

Abstract: This article investigates to what extent spaces created in the language introduction programme (LIP) in Upper Secondary School in Sweden close or open up for students' varied linguistic resources, to create an understanding of the implementational spaces of the educational environments that the school represents, and of the ideological underpinnings that these imply. In the analysis, schoolscaping is used based on displayed language on the school premises in combination with language practices in classrooms. The material analyzed consists of photographs, both from classrooms and shared spaces, together with field notes from observations. The analysis made conflicting ideologies visible. Although students were invited to use their languages in classrooms, these were rarely made visible in written form, which is remarkable as written language is given great value in school. The relative invisibility of the LIP students' languages in the schoolscape, except for in their own classrooms, together with the physical separation from other students at the school, paints a picture of expectations of assimilation and of a monolingual ideology, where the goal is that students become Swedish-speaking. Thus, the conclusion is that there are implementational spaces in the partly closed space that constructs LIP, while ideological spaces are rather closed.

Keywords: ideological and implementational spaces; language introduction programme; schoolscaping

\section{Introduction}

This article addresses questions of ideological and implementational spaces for students' varied linguistic resources in the Swedish Gymnasium (Upper Secondary

*Corresponding author: Åsa Wedin, Department och Languages, Litterature and Learning, Dalarna University, Falun, Sweden, E-mail: awe@du.se 
School, years 10-12 of formal schooling). Through linguistic schoolscaping, spaces for linguistic agency for recently arrived students are investigated in Språkintroduktionsprogrammet (the Language Introduction Programme, LIP), which is a transitional programme with the aim that students develop enough competence in Swedish to be able to attend education in the form of mainstream programmes. LIP is commonly organized parallel to mainstream programmes, and the forms of separation or integration have been a topic for debate and research (see for example Nilsson Folke 2017).

This study is part of a larger project on recently arrived students in Swedish Upper Secondary School. ${ }^{1}$ The main goal for this specific study is to investigate to what extent spaces created in the selected school, Cherry School, ${ }^{2}$ close or open up for students' varied linguistic resources. The specific aim is to create an understanding of the implementational spaces of the educational environments that the school represents, and of the ideological underpinnings that these imply. Through schoolscaping, that is linguistic landscaping in the educational space (see for example Szabó 2015), the space for translanguaging (Li 2011: 1233) in LIP is studied. Translanguaging is here used in accordance with Lindahl (2015) as the seamless shuttling between varied linguistic resources. Thus, the article focuses on the displayed images, objects, symbols and written language as well as activities, identities and discursive interactions that are indexed and promoted through the schoolscape at this educational site.

Treating the schoolscape of Cherry School as translanguaging spaces directs the interest toward the enactment of language ideologies, which may fill a research gap identified by Hua et al. (2017). In the Swedish setting, it is particularly interesting to investigate the role of the Swedish language hierarchy when it comes to language ideology (Hult 2012), where Swedish is usually given the highest status followed by English, while most other languages represented among students are low valued.

Following Szabó (2015), the interpretation of LIP in the school setting includes both oral and written language in the schoolscape. Through a study of the literacy objects at Cherry School together with the activities and interactions of those that inhabit the school (compare Todd Garvin and Eisenhower 2016), the study contributes to the understanding of LIP. The following research questions will guide the analysis in the study:

1 The project Recently arrived students in Swedish upper secondary school - a multidisciplinary study on language development, disciplinary literacy and social inclusion, 2018-2021, financed by the Swedish Research Council.

2 All names are pseudonyms. 
(1) Which implementational spaces for translanguaging become visible through displayed images, objects, symbols and written language at Cherry School?

(2) Which implementational spaces for translanguaging are opened through classroom practices?

(3) Which ideological underpinnings may be understood from the schoolscaping and classroom practices?

The concept implementational spaces, coined by Hornberger (2005) is used following Paulsrud and Zilliacus (2018) to denote spaces open for multilingualism with focus on linguistic resources. The concept ideological underpinnings is used here as underlying attitudes, norms and values in relation to linguistic repertoires.

\section{Language introduction programme}

LIP is a space for mobility, which includes mobility between spaces where different languages are given legitimacy, and thus LIP becomes a space for linguistic mobility, and as such a space where translanguaging becomes relevant. Young immigrants from the age of 16 are generally placed in LIP during the time it takes to reach required levels of Swedish, where they receive teaching in Swedish as a second language (SSL) and in different school subjects. According to the Swedish Education Act (SFS 2010:800), they should also receive what is called Study Guidance through the Mother Tongue (SGMT), which is language support in a language that the student understands for students who do not know enough Swedish to follow ordinary instruction in school subjects (Reath Warren 2017).

At Cherry School, LIP included between 65 and 125 students during the two years of field study, arranged in 5-10 classes, each assigned a teacher in SSL. Depending on earlier mapping procedures, students also studied other subjects that they needed to fulfil the requirements for mainstream programmes. This means that individual students had different schedules and joined different courses, apart from SSL. At Cherry School, there were also some mainstream programmes, but students in LIP studied physically separated from these students with very few exceptions, and mainly kept to their part of the school premises. This meant that LIP students studied SSL and other subjects in their own classrooms with their own teachers. Some of the classrooms were physically separated from other parts of the school through closed corridors with locked doors. The school had an entrance corridor and a central recreational area that was shared by the whole school, where students and teachers from all programmes spent break time. The partial separation from other programmes positions LIP as a space for transition. 


\section{Schoolscaping as an index of enacted language ideologies}

Linguistic landscaping (LL) has been developed as a tool for the analysis of material space (Blommaert 2013; Landry and Bourhis 1997; Szabó 2015). LL is particularly relevant when studying settings for minority languages; and Landry and Bourhis (1997) concluded in a foundational paper that the symbolic function of LL is strong when it comes to opening or closing spaces for identity development. Particularly in educational settings the occurrence of written language in the physical environment has significant impact on whether various languages are perceived as relevant and thus given space. According to Gorter and Cenoz (2014), minority languages will be more strongly present through visual LL in schools where spaces are opened for these languages through language policies.

Schools, as public institutions, are important spaces for the implementation, navigation and contestation of language policies and ideologies. Brown (2012: 282) defines the term schoolscape as "the school-based environment where place and text, both written (graphic) and oral, constitute, reproduce, and transform language ideologies". Through schoolscaping, "a focus on LL in schools offers an entry point for efforts to contest monolingual schooling and language hegemony by promoting bi/multilingual education” (Menken et al. 2018: 105).

Schools are treated as public spaces which are discursively constructed, negotiated and contested (Shohamy 2012), which means that, following Szabó (2015: 24), "the visual and spatial organization of public spaces indexes the coconstruction of ideologies in school settings".

The study of the role and significance of LL in educational spaces also implies that researchers consider schools as planned spaces, loaded with socially, culturally and historically situated interactions and rituals (Todd Garvin and Eisenhower 2016). Officially sanctioned texts such as labels, signs and written texts on walls, notice boards and tableaux, that is texts placed according to norms stipulated by authorities, display various cultural and linguistic norms, while literacy in the form of for example graffiti and scribbles may be signs of contestation or manifestation, what Pennycook (2009) calls transgressive signs.

Menken et al. (2018) argue that in schoolscaping not only the physical landscape needs to be considered, but also its connections to pedagogy, programming and language policies. Brown (2012) stresses the importance of the inclusion of oral language as part of the schoolscape. In this study, schoolscaping includes not only signs and written language, but human beings, oral language and interaction as well. 


\section{Methods and material}

This study is a part of a larger project, which aims to investigate several (inter-) related research questions about LIP-students' language development, disciplinary literacy and social inclusion, through a methodological frame of linguistic ethnography (Copland and Creese 2015; Martin-Jones and Martin 2017). Linguistic ethnography enables the understanding of complex phenomena, such as what implementational and ideological spaces for translanguaging are opened and closed in this specific educational site, LIP in Cherry School. The material analyzed here comes from two years of field studies, and consists of hundreds of photographs, both from classrooms and shared spaces, representing displayed images, objects, symbols and written language, together with field notes and recordings from observations. The school premises were photographed, with photographs representing both artefacts displayed only for a shorter period, such as advertisements for activities in the local environment, and signs displayed during the two years of observation, such as signs directing one towards different parts of the school premises. Ethical issues were considered to ensure that no school nor any person could be identified through the photos; and data is presented in ways that avoid recognition.

Observations were made for a total of $64 \mathrm{~h}$ of classroom instruction (8 in Natural Sciences; 9 in Social Sciences; 24 in Mathematics; 20 in SSL; one each in English; Mother Tongue Tuition in Arabic; and Fine Arts) and approximately $150 \mathrm{~h}$ in other areas of the school, such as corridors, entrance hall, central halls and leisure rooms. Photographs are from a of total eight classrooms. In this study, material from two selected lessons is used. Also, interviews with four individual students who were interviewed in relation to Natural science lessons are analyzed. These four were those, out of six students in the class, who volunteered to be video recorded and interviewed. Recordings were made after information about the study and only with those who gave their written consent.

In a first step, the implementational spaces for students' languages is studied through an analysis of the photographs of displayed images, objects, symbols and written language in the schoolscape. The importance of identifying agents such as authors, to identify top-down policies and bottom-up ideologies is highlighted by Biró (2016). This makes connections between LL and language ideologies and can give a deeper insight to the potential conditions like the hegemony of a dominant language or the invisibility of a minority language (Laihonen and Szabó 2017). Three main functions are used for the analysis, following Scollon and Scollon (2003), regarding how the displayed images, objects, symbols and written language do the following: 
1. Orient to place and space

2. Control behavior

3. Shape discourses

Here, time is added to the first, as time is often an important part in signs and messages displayed in schools. The images, objects, symbols and written language displayed are analyzed in terms of content, placement, languages, authorship, agency and recipient roles assigned or assumed.

In a second step, implementational spaces for translanguaging that are opened or closed through classroom practices are analyzed based on material from classroom observations. Finally, ideological underpinnings are analyzed drawing on the implementational spaces made visible through displayed objects, images, symbols and written language, as well as through classroom observations.

\section{Implementational spaces for translanguaging through displayed language}

When the function of displayed images, objects, symbols and written language in the school premises is in focus, it becomes clear that a specific sign may have several functions. The findings will be presented starting with the first research question.

\subsection{Orienting to place, space and time}

When arriving at Cherry School, the visitor, student or staff member meets a large sign on one wall on the outside of the building with the name of the school, claiming the space for the school. Inside the main entrance, there is a verbal welcoming sign and a sign that indirectly asks visitors to sign up at the reception desk to the left: "Besökare anmäler sig i receptionen" [Visitors sign up at the reception] in Swedish. In the entrance hall, there is also a schematic sign with a map of the school premises illustrating an evacuation plan (Figure 1). Similar maps, usually with escape routes marked, are found in different parts of the school. There are also signs with arrows showing where to get to different parts of the school (see Figure 2).

Other signs show the reception and the janitors' office with their opening times. These signs are more or less permanent, while other signage are more temporary, such as a display from twin school activities and some note-boards 


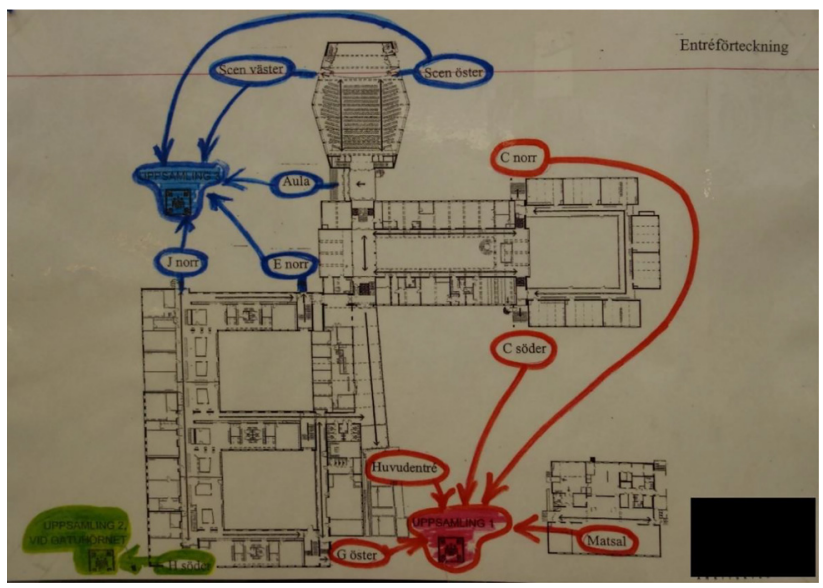

Figure 1: Evacuation plan.

with posters. One of these note-boards has information from the student counselor about various types of jobs and on the others (Figure 3), posters from external associations and clubs are displayed. There is also a digital information screen, but at the time for observations it was not working. All of these signs are only in Swedish, except for the posters from associations and clubs where English is also used.

In the center of the school building is a recreational area with tables and chairs and some screens that are used to divide the area. On the walls in this area, there are a few signs, such as a sign with opening hours for the library.

On the outside and inside of classrooms there were schedules and specific information, such as the time for SGMT for a particular class, a photograph of one

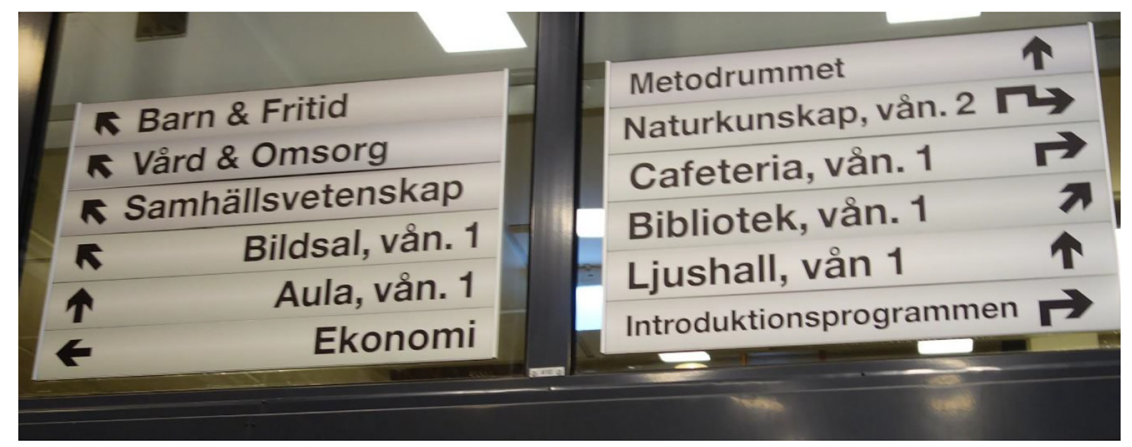

Figure 2: Signs showing how to get to various parts of the school. 


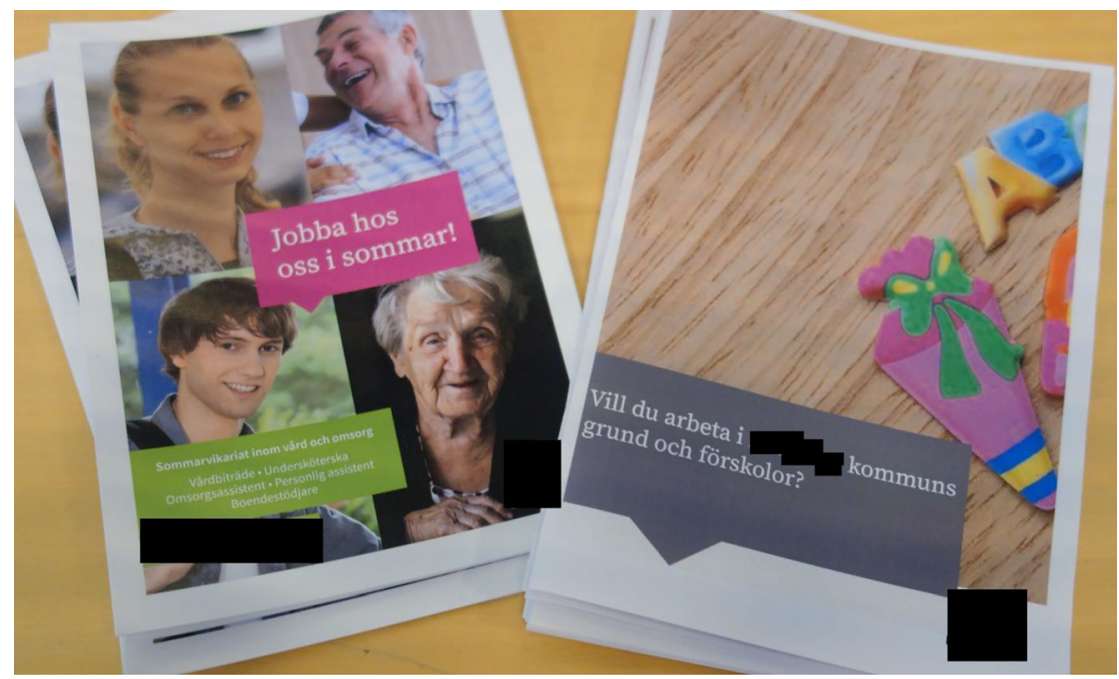

Figure 3: Information about various job opportunities.

class, grammar rules and time schedules for tests. On classroom walls not much was displayed, except for wall-calendars and in SSL-classrooms a few maps of Sweden, Europe or the world.

Only rarely was a language other than Swedish or English observed in this type of signage during data collection. One of the few examples was in one classroom where posters with the Swedish "Allemansrätten" [Legal right to access private land] were displayed. Allemansrätten enshrines the general public's right to and responsibility for access to privately owned property. This right holds a strong symbolic function in Sweden, and in this case it was translated to Arabic, Farsi and Somali.

In the orientation to space, time and place through signage at Cherry School, Swedish dominates. Also, the content in this signage may be said to represent a Swedish dominant context, and the only reference to other parts of the world comes in the form of recruitment to football clubs. Students' other linguistic resources and their own experiences from other parts of the world are basically invisible. Although authors and agents are not often expressed explicitly, in classrooms they are mainly teachers while in shared areas they may be understood as the school as an institution or the school administration, with the board for associations and clubs as one exception. Students are not visible as agents through the signage. Thus, students in LIP may be understood as recipients and not agents in this regard. 


\subsection{Controlling behavior}

When the second function is considered, to control behavior, displayed images, objects, symbols and written language are mainly directed towards students and visitors, and to a lesser extent to school staff. The school as institution may be implied as authors and agents, through janitors, representatives for the municipality or school administration. Some signage is clearly displayed to control behavior, such as rules of conduct. These signs are more or less directed towards students and may be understood to have been authored and displayed by the school as institution or teacher(s), but commonly the author is not explicitly stated.

In some of the signs, the message is not explicit but rather implicit, such as "trivselregler" (rules for well-being) found in one classroom, as well as signs claiming the school as a non-smoking and perfume-free area (Figure 4).

The choice of more implicit expressions instead of more explicit alternatives, such as "smoking is prohibited", "use of perfume is not allowed" and "rules of conduct", may be perceived as a common strategy in Sweden, particularly in school settings, where more implicit forms are common. This may perhaps be understood as a way to create a sense of equality and democracy, where rules are something that "we" have agreed on and are expected to follow (by our free will). They may be understood as agreements rather than rules and to some extent creating a discourse: "Here, we are together and we have a common agreement on certain forms of behavior". It may be understood as creating an egalitarian relationship, although students are also here positioned as recipients who are to follow the rules, but preferably of their own will.

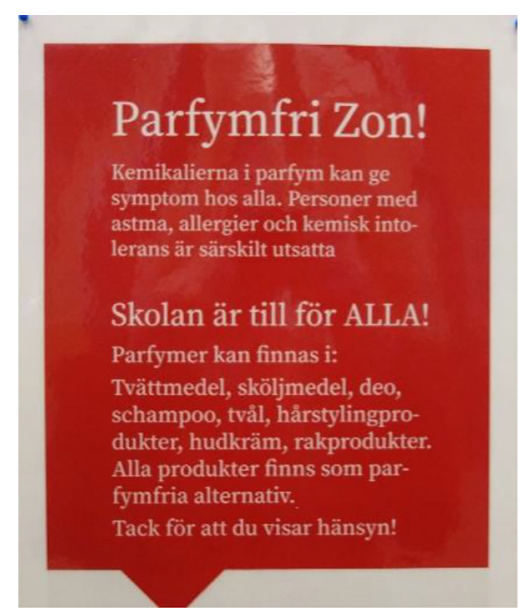

Figure 4: Poster for the school as a perfume free zone. 


\subsection{Shaping discourses}

The discourse of equality and democracy present through signage that expresses rules of conduct implicitly is also visible on a wall that is newly painted with the text "På Hägg möter du lärare som bryr sig” (In Cherry you meet teachers who care) in white on silver. This may be understood as addressing both teachers and students, expressed as what you should expect (as student) and follow (as teacher).

In posters and advertising from external clubs English is common together with Swedish (Figure 5).

The poster in Figure 5 is written in English only, addressing those who would like to make a football career abroad. The choice of English may hint at internationalism but to the English-speaking part of the world that the reader is assumed to be part of. The individuals represented in the photos are young men with light skin and bleached hair. As most of the students in LIP have black hair and a large proportion have dark skin, they are to that extent not visibly represented through that poster, and no poster was observed during the study representing non-white young persons. The posters may thus be understood as creating a discourse of young people rethinking language and life with Swedish and English as the languages used, while not making experiences and origins from other parts of the world visible.

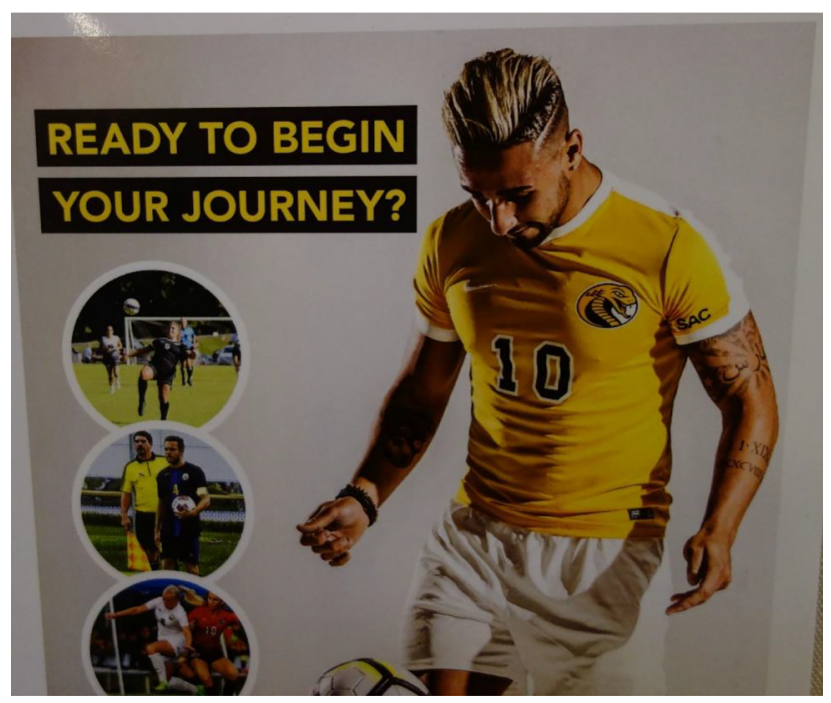

Figure 5: Recruitment to a football club. 
The discourse made visible through this signage does not open much space for translanguaging, expect for use of Swedish and English, and the diverse linguistic resources among students and school staff are not represented. Surprisingly there was an absence of transgression, such as scribbles, written language or other signage that may be perceived as provocative. Perhaps one poster displayed in a place that was not prescribed may be referred to as transgressive through its placement. This was a sign for "Fridays for the future", that is school strikes for the climate, which one Friday was attached to one of the entrance doors, using tape (Figure 6). It is not known to me who put this post up er and it was displayed only a few days.

Thus, the discourse made visible through signage at Cherry School is a discourse where students in LIP are quite invisible and do not act as authors. The discourse may rather be understood as expressing a "we", but not through the representation of LIP students and without giving space to their voices or agency. Still, the discourse is inviting, and students are implicitly welcomed to become included in the implicit "we". The example with the translation of the legal right to access to private land may in this context be understood as an inclusive discourse where students are invited to become like "us", Swedes who are expected to care about this rule.

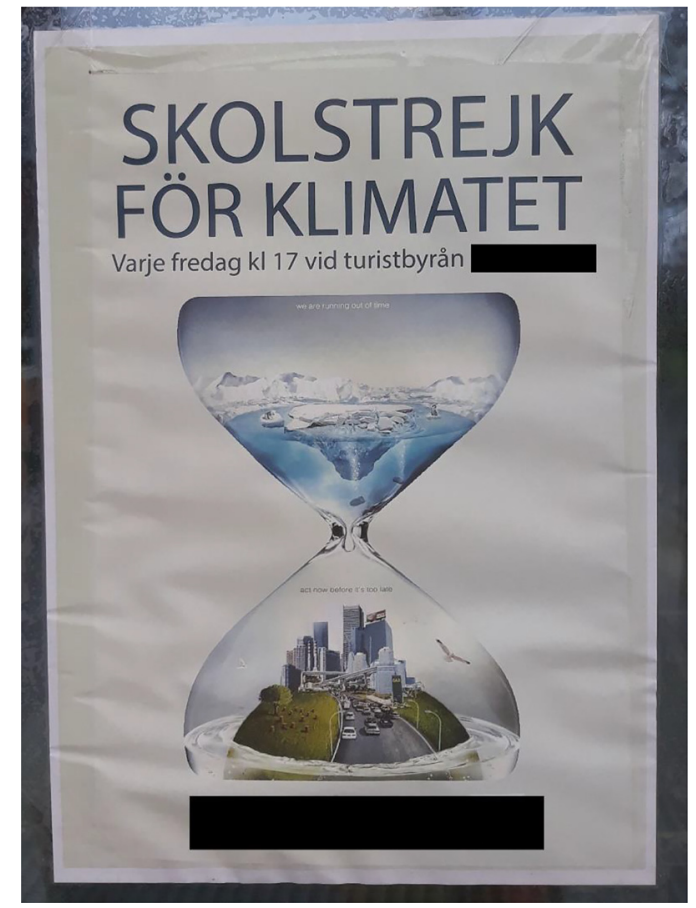

Figure 6: Poster for school strike for the climate. 


\section{Implementational spaces for translanguaging in classroom education}

While students' various linguistic resources and agency were nearly invisible through images, objects and symbols in the school premises, in classrooms their varied language resources were used in different ways in all observed lessons and students were also invited to do so. Students had access to the internet and various software through laptops that they were provided with individually during their studies at LIP. Most students also used their private mobile phones in class. Through these digital tools, they had access to educational films with talk and comments in diverse languages, as well as reading services with oral translations of textbooks. Teachers invited students to use these, particularly in Social Sciences and in Natural Sciences, and all students were observed to use translation tools such as Google translate, and to some extent they also looked particular words up through Wikipedia or searched for pictures, for example of the concepts "lövskog" [deciduous forest] and "barrskog" [coniferous forest] (Figure 7). In some lessons, SGMT assistants were present and helped students through various languages.

First, two lessons with spaces for translanguaging will be presented to show how teachers used varying approaches to multilingualism resulting in varied practices with regard to how the lesson opened or closed spaces for translanguaging. The is a lesson in Physics and the second from Mathematics.

\subsection{Inviting translanguaging in lesson on sound}

In the selected lesson in Physics, the teacher Maria only had five students who all aimed at fulfilling the learning requirements later that term. The main languages

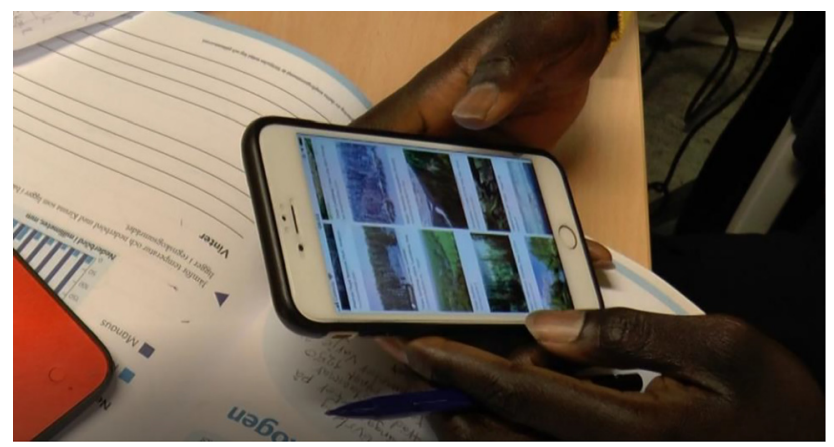

Figure 7: Student looking up concepts on the mobile in relation to exercises. 
that these students use apart from Swedish are French, Arabic, Kormanji, Somali, Thai and Dari. The topic was sound and Maria illustrated sound and the vibrations of the sound using a tuning fork. She explained in Swedish that the fork "sätts $i$ vibration och förstärker och förtunnar luften" [vibrates and amplifies and thins the air]. She talked about musical instruments, took out a flute on which she played a traditional song from the local area, and she described sound waves and the amplification of sound. Students were given a handout with words and concepts and the task for the unit was that students should be able to describe the meaning of these. She asked students to start to find the meanings "På vilket språk som helst" [in any language], reminded them to use the reading services, and suggested an instructional film that had translation either through sound or subtitles in some of the languages that students knew. All students took out their laptops and started to look up the meaning of the words in the list through various languages. In the lesson, they googled the words, used Wikipedia, and listened to translations of the textbook through the reading services. Some watched the instructional film. One of the students wrote her own translation in Thai, which she retrieved through Google translate, on the handout. Another student explained after a direct question from the researcher on what she does to learn the words: "jag lyssnar först på arabiska, sen på svenska" [I first listen in Arabic, and then in Swedish]. Thus, students made use of their varied linguistic resources through various media to be able to give explanations of the words and concepts in the assessment. However, apart from inviting students to use multilingual resources, Maria did not check whether students had understood. She told students that during the assessment the following lesson they would be asked to pick among the concepts and to give a short explanation.

Through this teaching, students were invited to use their varied linguistic resources, but they were to a great extent left on their own to find successful ways to navigate between languages. Some of their languages were available in various ways, while some, such as Dari, Kormanji and Thai were only available to a restricted extent. Thus, different students used different translanguaging strategies. Their focus was on finding translations and explanations of the words to write down. Spaces opened for translanguaging only included students, and the teacher kept herself outside this space. When students had questions, they rather turned to their classmates than asked Maria. The same pattern is observed in other lessons observed with Maria, for example in lessons where there was an SGMT assistant speaking one or more of students' other languages, Maria did not involve herself in the discussions following students' questions to the assistant.

Languages other than Swedish were used as tools to learn what was valued which was to express the knowledge in Swedish. It may be noted that while Maria explained the topic, she rarely explained specific words and never referred to how 
these concepts could be expressed in other languages. However, three of the four interviewed students claimed that they already knew the content through their earlier schooling before they came to Sweden, and that what they needed was to learn how to express this in Swedish. Thus, there may be said to be an ambivalence in the teacher's goal for the lesson and some of the students', as the teacher's focus was on teaching the content and not on teaching language. There is a risk for misunderstanding when the teacher does not explain important concepts, such as in the introduction of this lesson when she says "vibrates and amplifies and thins the air" without further explanations of the concepts and without checking students' understanding. As for example Swanson et al. (2014) and Ünsal et al. (2016) have shown, it is problematic to rely entirely on students' own understanding through translations as these may obscure understanding. This risk was particularly high for the student who did not know the content earlier.

Thus, this lesson may be said to open space for translanguaging, while the teacher did not involve herself in the negotiation of meaning that mainly took place through varied languages, but this was left to students in collaboration with the SGMT assistants on the occasions when they were present.

\subsection{Including translanguaging in all parts of a lesson on the decimal system}

The second selected lesson is a lesson in Mathematics, with a group of students with no or little earlier schooling (see also Wedin 2021a). During this lesson, there were five students in the classroom, who apart from Swedish knew Kurdish (Gulan), Somali (Maxamed, Osman and Hani) and Dari (Sarwar). The teacher, Khaled, speaks Farsi, which is linguistically very similar to Dari. There was also an SGMT assistant, Suleymaan, who speaks Somali and Arabic. Khaled, Suleymaan and the students use their various linguistic resources in their negotiation for meaning. Even though the Kurdish-speaking student only shared her limited Swedish with the others, both Khaled and the assistant tried to use some Arabic and English together with mathematics material when they explain concepts to her. In this lesson, Khaled assigned individual work to two of the students, while he arranged three of them, Gulan, Maxamed and Osman, to work together with him on the decimal system. He started by repeating the principles of the decimal system, units, tens, hundreds and thousands. He poured out material on the desk in front of the three, magnetic figures resembling units, tens, hundreds and thousands together with fake money. He demonstrated how to use the money, put the magnetic figures on the whiteboard, writes '2785' and showed how the magnetic figures can be arranged to represent the same number, asking students to do the 
same on the bench in front of them. When Maxamed had problems carrying out the task, Osman helped him through Somali and by showing him with the materials on the bench.

Khaled then wrote three four-digit numbers on the blackboard and asked students to go up to the board and to represent these using the magnetic figures. While they worked, Khaled and Suleymaan discussed the solutions with the individual students, pointing to the figures and digits and orally expressing the fourdigit numbers and the number of units, tens, hundreds and thousands that they represented.

During the rest of the lesson, students worked with exercises on handouts while Khaled and Suleymaan walked around and helped them individually. Through this work process, verbal language, with Swedish dominating, was only part of the modalities used. Thus, for Khaled Swedish was the main verbal language to use with these three students, combined with some English and Arabic. However, as became visible through the work process, other modalities were important for the negotiation of meaning in this Mathematics lesson. Apart from the mentioned fake money, magnetic figures and written digits, Khaled also used embodied expressions, for example when one student asked the meaning of 'order of magnitude' he used his body including his own clothes to demonstrate small, medium and large. Thus, in the negotiation of meanings, the teacher shuttled between oral and written language, materials and embodied language. This fluidity of languaging may be compared to translanguaging practices described as 'seamlessness' by Lindahl (2015) from a sign-language classroom, and in this Mathematics classroom this may be described as shuttling in the form of anchoring (Wedin 2021b), where the teacher started with the four-digit number '2785', said the number-name orally 'two-thousand-seven-hundred and eighty-five', constructed the number in material form, and returned to the four-digit number. Thus, the shuttling started and ended with the mathematical expression with other types of representations that are closer to students' experiences in their daily lives in between. Khaled not only used his own linguistic resources with the students, but also varied modalities to explain and create patterns for students to negotiate meaning by shuttling between various resources.

\subsection{Implementational spaces for translanguaging in the two lessons}

The two teachers' strategies as far as linguistic resources, digital tools and varied modalities are concerned are similar when it comes to inviting students to use their varied languages. Students' diverse linguistic resources were tolerated, and they 
were invited to use them through various media. However, there is a difference between Maria and Khaled whether they take part in the negotiation of meaning that is done through translanguaging. This affects the role and status given the translanguaging space, either as something valuable for all, including the teacher, or as something for students to use to reach their goal, to fulfill the requirements where only Swedish is valued. Thus, classroom practices here may be said to open up for translanguaging, but the difference between the two teachers affected the status given both to students' varied linguistic resources and to translanguaging.

It may be argued that Maria only shared Swedish with her students, while Khaled and the SGMT assistants shared also other languages. However, if translanguaging is understood as the seamless shuttling that Lindahl (2015) refers to and as including all linguistic resources, including oneself in the negotiation through varied resources is not restricted to those who share languages. In Khaled's classroom, for example, Gulan was not excluded from the negotiation through translanguaging, and Khaled and the SGMT assistant both were involved in translanguaging with all students, creating a translanguaging space (Li 2011) were the norm was shuttling between linguistic resources and modalities. By excluding herself from the ongoing negotiation through translanguaging in her classroom, Maria excluded herself from part of the meaning-making that was done there and thus students missed out on her knowledge in an important space for developing scientific knowledge.

\section{Ideological underpinnings understood from the schoolscaping and classroom practices}

Although students' linguistic resources were invited in classrooms and in learning practices, the schoolscaping made a strong Swedish discourse visible where English was given some value through signage, while students' linguistic resources other than Swedish or their experiences from other parts of the world were made more or less invisible. However, the two lesson examples revealed differences with regard to the use of linguistic resources and translanguaging, either as something valuable for all or as a (necessary) tool for others. This makes two diverging ideologies visible, one of LIP as a space where language is seen as a resource for all, and the other where we and them becomes visible, where they may use their languages to become like us. This becomes an ambivalence in ideologies regarding language, where languages other than Swedish (and to some extent English) on the one hand are tolerated, while on the other hand they are not valued. While an explicit ideology of the value of diverse languages is visible when students are 
invited to use them in classroom work, implicitly what counts for further studies and entrance to mainstream programmes and thus to space outside LIP is Swedish (and English). Except for the example from the Mathematics classroom, this paints a picture where LIP students' linguistic resources, as well as their earlier experiences, are tolerated and invited to a certain extent, but not valued, and of an underlying monolingual ideology, or rather Swedish-English ideology, devaluing other linguistic resources.

This may be in line with the transitional nature of LIP, but rather paints a picture of separate spaces with varying degree of visibility of other languages than Swedish. The translanguaging space in classrooms, made visible in students' work and interaction between themselves and SGMT assistants, gives an impression of constituting a rather closed space in which Khaled entered but not Maria. This also opens for discussions of the representation of and assigned value to oral and written modes.

\section{Discussion}

The enactment of language ideologies becomes visible in the space that LIP constitute (Hua et al., 2017). Translanguaging appears as invited and used but not valued, as something to use in transition. The schoolscaping, through displayed images, objects, symbols and written language in combination with classroom practices included oral language in the schoolscape (Brown 2012; Hult 2012; Todd Garvin and Eisenhower 2016) as well as pedagogical aspects such as language practices in classrooms (Menken et al. 2018), which made conflicting ideologies visible. The invisibility of the LIP students in the schoolscape, except for in their own classrooms, together with the physical, and to some extent social, separation from other students at the school, paints a picture of expectations of assimilation and a monolingual ideology, with the goal that students become Swedishspeaking and follow Swedish norms. The schoolscape gives an ambivalent impression, where the LIP students are invited to use their varied linguistic resources, while these are invisible in the school space, as are students' bodies and earlier experiences. In their own classrooms, where they are separated from other students and teachers and from other parts of the school, the linguistic diversity is audible and visible through students' voices and digital tools, but in the two selected lessons the value signaled of students' linguistic resources varied. Although students were invited to use their languages, these were rarely made visible in written form or displayed, which is remarkable as written language is given great value in school. 
LIP is a transitional programme and the goal is to move on through admission to mainstream programmes, which are represented in the school premises through the space where students' linguistic resources other than Swedish are made invisible. Although spaces were opened for translanguaging in their classrooms, the invisibility in other spaces was never observed to be contested, either through the schoolscaping or through the observations in classrooms and in other school premises. On the whole, student agency and transgression (Pennycook 2009) were surprisingly absent. Thus, the conclusion is that there are implementational spaces for translanguaging in the partly closed space that constructs LIP, while ideological spaces are rather closed. The schoolscape and its participants coconstruct an ideology where Swedish language and norms become the goal, while space is not open for translanguaging in high-valued ways.

\section{References}

Blommaert, Jan. 2013. Ethnography, superdiversity and linguistic landscapes: Chronicles of complexity. Bristol: Multilingual Matters.

Brown, Kara. 2012. The linguistic landscape of educational spaces. In Heiko Marten, Durk Gorter \& Luke van Mansel (eds.), Minority languages in the linguistic landscape, 281-298. Basingstoke: Palgrave Macmillan.

Copland, Fiona \& Angela Creese. 2015. Linguistic ethnography collecting: Analyzing and presenting data. Los Angeles: Sage.

Gorter, Durk \& Jasone Cenoz. 2014. The linguistic landscapes inside multilingual schools. In Spolsky Bernard, Micha Tannenbaum \& Ofra Inbar-Lourie (eds.), Challenges for language education and policy: Making space for people, 151-169. New York: Routledge.

Hornberger, Nancy. 2005. Opening and filling up implementational and ideological spaces in heritage language education. The Modern Language Journal 89(4). 605-609.

Hua, Zhu, Wei Li \& Agnieszja Lyons. 2017. Polish shop (ing) as translanguaging space. Social Semiotics 27(4). 411-433.

Hult, Francis. 2012. English as a transcultural language in Swedish policy and practice. TESOL Quarterly 46(2). 230-257.

Laihonen, Petteri \& Tamás P. Szabó. 2017. Investigating visual practices in educational settings: Schoolscapes, language ideologies and organizational cultures. In Marilyn Martin-Jones \& Deirdre Martin (eds.), Researching multilingualism: Critical and ethnographic perspectives, 121-138. London: Routledge.

Landry, Rordigue \& Richard Bourhis. 1997. Linguistic landscape and ethnolinguistic vitality: An empirical study. Journal of Language and Social Psychology 16(1). 23-49.

$\mathrm{Li}$, Wei. 2011. Moment analysis and translanguaging space: Discursive construction of identities by multilingual Chinese youth in Britain. Journal of Pragmatics 43(5). 1222-1235.

Lindahl, Camilla. 2015. Tecken av betydelse: En studie av dialog i ett multimodalt, teckenspråkigt tvåspråkigt NO-klassrum [signs of importance: a study of dialogue in a multimodal signing bilingual natural science classroom]. Stockholm: Stockholm University Dissertation. 
Martin-Jones, Marilyn \& Deirdre Martin. 2017. Researching multilingualism: Critical and ethnographic perspectives. London: Routledge.

Menken, Kate, Pérez Rosario, Vanessa, Guzmán Valerio \& Luis. 2018. Increasing multilingualism in schoolscapes: New scenery and language education policies. Linguistic Landscape 4(2). 101-127.

Nilsson Folke, Jenny. 2017. Lived transitions: Experiences of learning and inclusion among newly arrived students. Stockholm: Stockholms Universtitet Dissertation.

Paulsrud, BethAnne \& Harriet Zilliacus. 2018. Flerspråkighet och transspråkande i lärarutbildningen. In BethAnne Paulsrud, Jenny Rosén, Boglárka Straszer \& Åsa Wedin (eds.), Transspråkande i svenska utbildningssammanhang [translanguaging in Swedish educational settings], 27-48. Lund: Studentlitteratur AB.

Pennycook, Alistair. 2009. Linguistic landscapes and the transgressive semiotics of graffiti. In Elana Shohamy \& Durk Gorter (eds.), Linguistic landscape: Expanding the scenery, 302-312. London: Routledge.

Reath Warren, Anne. 2017. Developing multilingual literacies in Sweden and Australia: Opportunities and challenges in mother tongue instruction and multilingual study guidance in Sweden and community language education in Australia. Stockholm: Stockholms Universitet Dissertation.

Scollon, Ron \& Suszie W. Scollon. 2003. Discourses in place: Language in the material world. London: Routledge.

SFS 2010:800. Skollag [education act]. http://www.riksdagen.se/sv/dokument-lagar/dokument/ svensk-forfattningssamling/skollag-2010800_sfs-2010-800 (accessed 13 August 2016).

Shohamy, Elana. 2012. Linguistic landscape and multilingualism. In Marilyn Martin-Jones \& Alistair Blackledge (eds.), The Routledge handbook of multilingualism, 538-551. London: Routledge.

Swanson, Lauren H., Julie A. Bianchini \& Jin S. Lee. 2014. Engaging in argument and communicating information: A case study of English language learners and their science teacher in an urban high school. Journal of Research in Science Teaching 51(1). 31-64.

Szabó, Tamás P. 2015. The management of diversity in schoolscapes an analysis of Hungarian practices. Apples - Journal of Applied Language Studies 9(1). 23-51.

Todd Garvin, Rebecca \& Kristina Eisenhower. 2016. A comparative study of linguistic landscapes in middle schools in Korea and Texas: Contrasting signs of learning and identity construction. In Robert J. Blackwood, Elisabeth Lanza \& Hirut Woldemariam (eds.), Negotiating and contesting identities in linguistic landscapes, 215-232. London: Bloomsbury Publishing.

Ünsal, Zeynep, Britt Jakobson, Bengt-Olov Molander \& Per-Olof Wickman. 2016. Science education in a bilingual class: Problematizing a translational practice. Cultural Studies of Science Education 13(2). 317-340.

Wedin, Åsa. 2021a. Languaging in mathematics classrooms: Space for students’ varied language repertoires in the Language Introduction Program in Sweden. Nordic Studies in Mathematics Education 26(2). 67-85.

Wedin, Åsa. 2021b. Languaging in the mathematics classrooms: Space for students' varied language repertoirs in the language introduction program in Sweden. Nordic Studies in Mathematics Education 26(2). 101-119. 